\title{
Allelopathy in two species of Chenopodium - inhibition of germination and seedling growth of certain weeds
}

\author{
SUBHASH CHANDRA DATTA, KASI NATH GHOSH
}

Department of Botany, University of Calcutta, Calcutta - 700019, West Bengal, India (Received: April 1, 1985. Revision accepted: November 5, 1986)

\begin{abstract}
The activity of washed leaf and inflorescence material of Chenopodium ambrosioides and $C$. murale, decaying leaves and inflorescences, and field soils collected beneath Chenopodium plants were examined in terms of the inhibition of seed germination and seedling growth of five weeds, viz. Abutilon indicum, Cassia sophera var. purpurea, C. tora, Evolvulus numularius and Tephrosia hamiltonii. The allelopathic pattern varied in each of the two test species and this depended on the type of test matter. However, the germination as well as the root and hypocotyl growth of $A$. indicum and E. nummularius were more hampered by phytotoxins or inhibitors from Chenopodium than were the other weeds. Since the leaf and inflorescence of Chenopodium formed the source of inhibitors, the respective plant-parts from the two species were chemically analysed and the presence of three terpenes (p-cymene, ascaridole and aritazone) from $C$. ambrosioides and an organic acid (oxalic acid) from $C$. murale were implicated in the allelopathic effect.
\end{abstract}

Key words: decaying plant-parts, field soils, inhibitors, phytotoxicity, washed plant material

\section{INTRODUCTION}

Chenopodium ambrosioides $\mathrm{L}$. is a tall glandular herb bearing oblong-lanceolate leaves, flowers in simple or panicled spikes and obtuse seeds. A native of Mexico, it is a recently introduced weed in India and found in distributed waste places along roadsides and near gardens (Maheshwari 1963). This species is distributed in Kashmir, Panjab, Bihar, Maharashtra, the Deccan and Western Ghats up to 7,000 ft above sea level (Chopra et al. 
1965, Masheshwari and Singh 1965). C. murale L. is a rather low herb with deltoid-ovoid leaves, flowers in axillary spikes arranged in spreading cymes and rugose seeds. It is of widespread occurrence in India, extending to West Asia, North Africa and Europe but introduced in North America (Datta et al. 1978). In West Bengal, the plant largely emerges in well-ploughed, irrigated and cultivated lands. It grows in field-crops, such as brinjal (Solanum melongena L.), gourd (Cucurbita maxima Duchesne), mustard (Brassica campestris L. var. dichotoma Watt.), potato (Solanum tuberosum L.) and wheat (Triticum aestivum Lamk.). While dwelling in plantations of these crops, Chenopodium murale undoubtedly exists as an aggressive and harmful weed. Bhati et al. (1979) also noted its infestation as "most severe in wheat fields which caused stunting and poor growth of crops". While C. ambrosioides flowers from April to September in the vicinity of Calcutta, the flowering period of $C$. murale extends from December to March. In C. ambrosioides, the plant emits a vigorous camphoraceous odour and excludes other species in its habitat. On the other hand, C. murale is not so aromatic. Nevertheless, it also exerts a direct or indirect influence on the normal growth of the crop species listed earlier. Anything which prevents a seed from sprouting and discourages a species from thriving, must have a powerful influence on the composition of the plant community (Salis bury 1957). This could perhaps indicate an allelopathic effect and led to a comprehensive study, revealing the prevalence of germination and growth inhibitors in both $C$. ambrosioides and $C$. murale. According to Putnam and Duke (1978), allelopathy may be a habitat factor in enhancing dominance by certain weeds in a variety of agro-ecosystems. Harper (1977), who is not fully convinced of the reality of toxic interactions in nature, described the literature concerning interactions between plants as unsatisfactory and yet stimulating.

This project embodies the results on the effects of plant-parts of $C$. ambrosioides and $C$. murale on the seed germination as well as the root and hypocotyl lengths of five weeds, such as Abutilon indicum (L.) Sw., Cassia sophera L. var. purpurea L., C. tora L., Evolvulus nummularius (L.) L. and Tephrosia hamiltonii J. R. Drumm.

\section{MATERIAL AND METHODS}

Leaves and inflorescences from Chenopodium ambrosioides and C. murale were collected during 1976-1978 and washed in glass-distilled water. Extracts were prepared by crushing $100 \mathrm{~g}$ tissues in a Bajaj mixer with water. Leachates were made by soaking equal amounts of fresh material in water for $72 \mathrm{~h}$. Each type of extract or leachate was filtered through Whatman 
(No. 1) filter paper and the filtrate brought to $250 \mathrm{~cm}^{3}$ with additions of water. This constituted the stock inhibitor solution $(1: 2.5)$ from which desired concentrations (1:5, 1:10 and 1:20) were obtained by way of dilution. Each bioassay consisted of placing 25 seeds in a sterile. Petri-dish $(11 \mathrm{~cm}$ diam) which contained one thickness of filter paper and $10 \mathrm{~cm}^{3}$ test solution or water. There were four replicates per experiment. Before each experiment, weed seeds were scarified (with conc. $\mathrm{H}_{2} \mathrm{SO}_{4}$ for $20 \mathrm{~min}$ in Cassia sophera var. purpurea, C. tora, Evolvulus nummularius and Tephrosia hamiltonii and for $2 \mathrm{~h}$ in Abutilon indicum) to eliminate coat-imposed dormancy and washed thoroughly in water. Germination and seedling growth was recorded after 5 days. Rïsults are expressed as percent of control.

In order to ascertain whether washed leaves and inflorescences can retain phytotoxicity, $200 \mathrm{~g}$ each plant-part were taken in a cloth bag and dipped in running water for $24 \mathrm{~h}$. Leaf or inflorescence tissues were divided equally into two batches one to obtain the extract and the other for further soaking $(24 \mathrm{~h})$ to obtain the leachate. Weed seeds were treated with the extract and leachate thus prepared.

To judge the activity of the decaying plant-parts, leaves and inflorescences of Chenopodium were collected and allowed to wither away for 40 days. These were ground thoroughly and mixed with loamy soil $(250 \mathrm{~g})$ at the rates of $2,4,8,16$ and $32 \mathrm{~g}$ of plant material. Such mixtures were placed in Petri-dishes, covered with filter paper, wetted with $10 \mathrm{~cm}^{3}$ of water and weed seeds scattered on the moist surface of the paper.

To find out the effectiveness of inhibitors leaching out from test species, soils inhabited by $C$. ambrosioides were collected in April (pre-monosoon), August (monsoon) and October (post-monsoon) whereas those inhabited by C. murale in November (post-monsoon), January (winter) and March (pre-monsoon). From each sample, some soil quantities were transferred to Petri-dishes where different weed seeds were sown after inserting a filter paper and pouring $10 \mathrm{~cm}^{3}$ water. Soils collected from the same areas but not infested with Chenopodium served as controls.

The leaf and inflorescence of the two species of Chenopodium were extracted with acetone or methanol. The extract obtained from each solvent was assayed for inhibitory capacity against the seed germination of mustard (Brassica' campestris var: dichotoma). Each extract was concentrated, fractionated and purified by column chromatography. After purification each

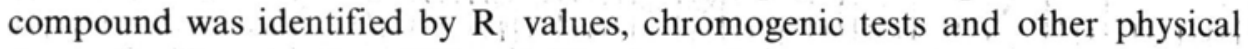
properties like mp, bp, UV and IR absorption spectrum. 


\section{RESULTS}

Extract and leachate of washed plant-parts. Inhibitor solutions of higher concentration (1:2.5 and 1.5) did not encourage seed germination and seedling growth of Abutilon indicum (Fig. 1). Even at lower concentrations (1:10 and $1: 20$ ), with the exception of weakest Chenopodium murale inflorescence-extract, there was little or no response of Abutilon in the presence of extracts and leachates.

As regards Cassia sophera var. purpurea, there was generally appreciable germination and seedling growth with the inhibitor solution of highest concentration (Fig. 1). At 1:10 and 1:20 concentration, seedling growth was more inhibited by the extract than by the leachate and more by Chenopodium murale than by $C$. ambrosioides. However, germination of Cassia seeds was more adversely affected by the leachate than by the extract.

At lower concentrations, inhibitor solutions yielded greater germination and seedling growth of Cassia tora in most cases (Fig. 1). With higher concentrations, leachates were more toxic to this weed than the corresponding extracts and generally Chenopodium ambrosioides more effective than C. murale.

As to Evolvulus nummularius, the strongest concentration of Chenopodium inhibitor solution fully suppressed seed germination and seedling growth (Fig. 1). At 1:5 concentration, the leachate of $C$. ambrosioides inflorescences was more inhibitory than that of the extract and the extract of the $C$. murale inflorescences more than that of the leachate. At 1:20 concentration, the inhibitor solution from Chenopodium inflorescences was more effective on germination than on seedling growth and the extract of $C$. murale leaves inhibited both processes of Evolvulus more than the leachate of corresponding leaves.

Up to 1:5 concentration, Chenopodium murale inhibitor solution was more effective against Tephrosia hamiltonii than $C$. ambrosioides and this was more for the solution from leaves than from inflorescences (Fig. 1).

Fig. 1. Germination (-), root length $(\bigcirc)$ and hypocotyl length $(\triangle)$ of various weeds in the presence of extracts (-) and leachates (--) of washed $(24 \mathrm{~h})$ Chenopodium leaves and inflorescences

Analysis of variance

Germination

Root length

Hypocotyl length

Between the levels of:

Concentration

Test species

Test organs

Treatment

Weeds

$\times$ Significant at $1 \%$. NS - not significant. 
LEAF
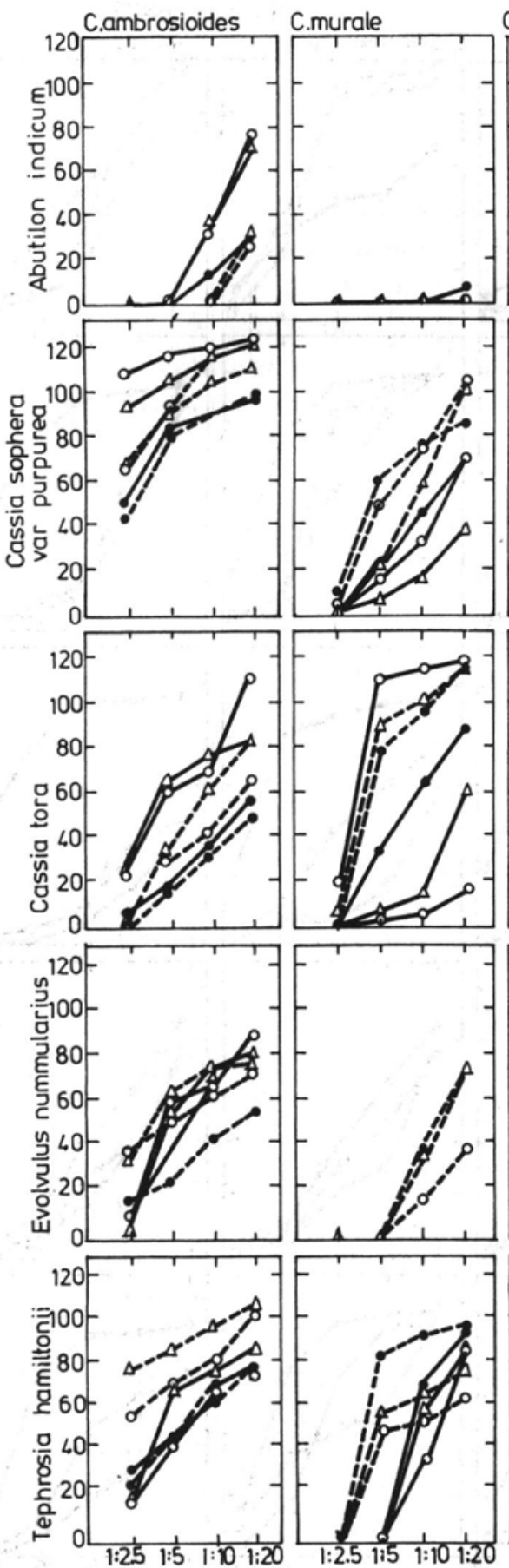

INFLORESCENCE C.ambrosioides, C.murale
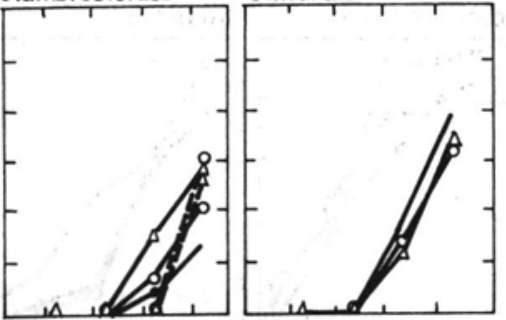
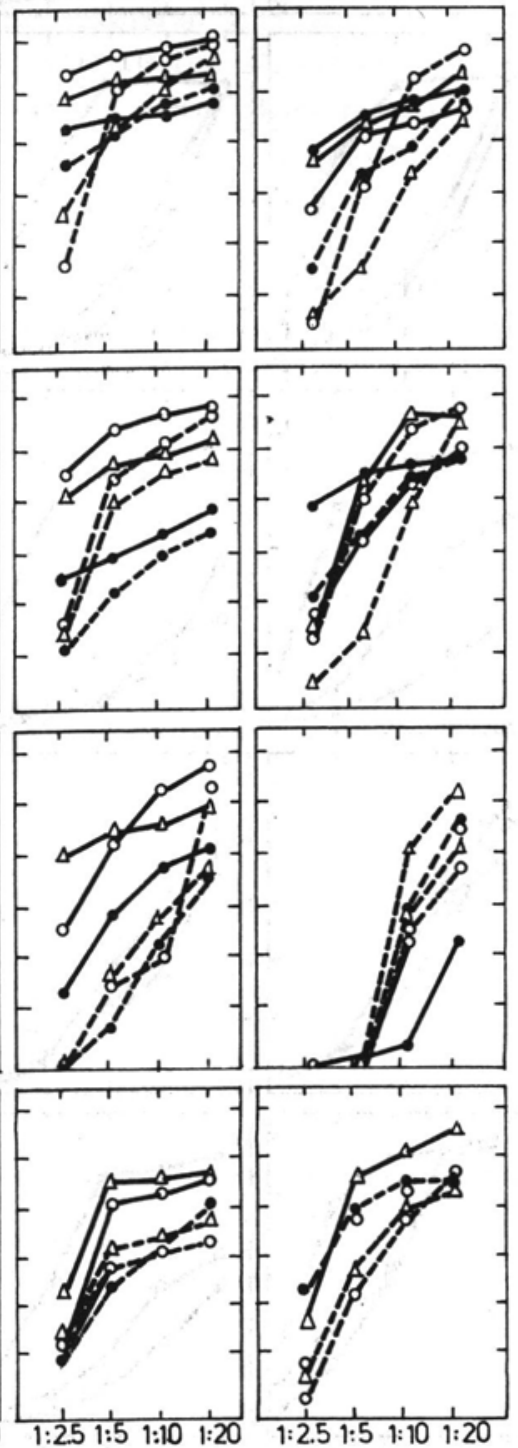
LEAF
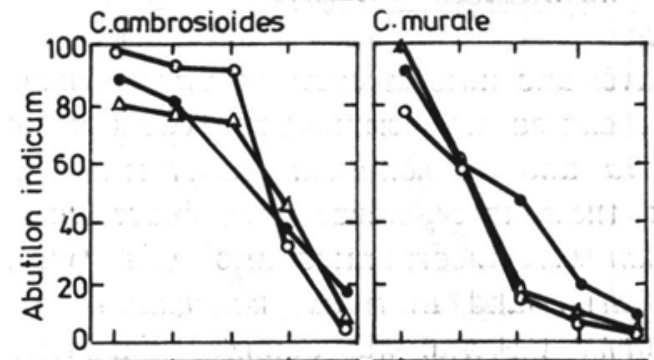

C.ambrosioides

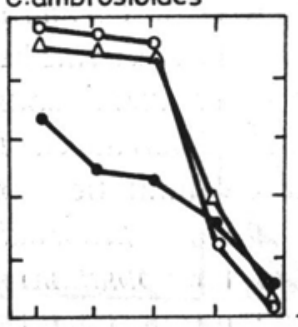

C.murale
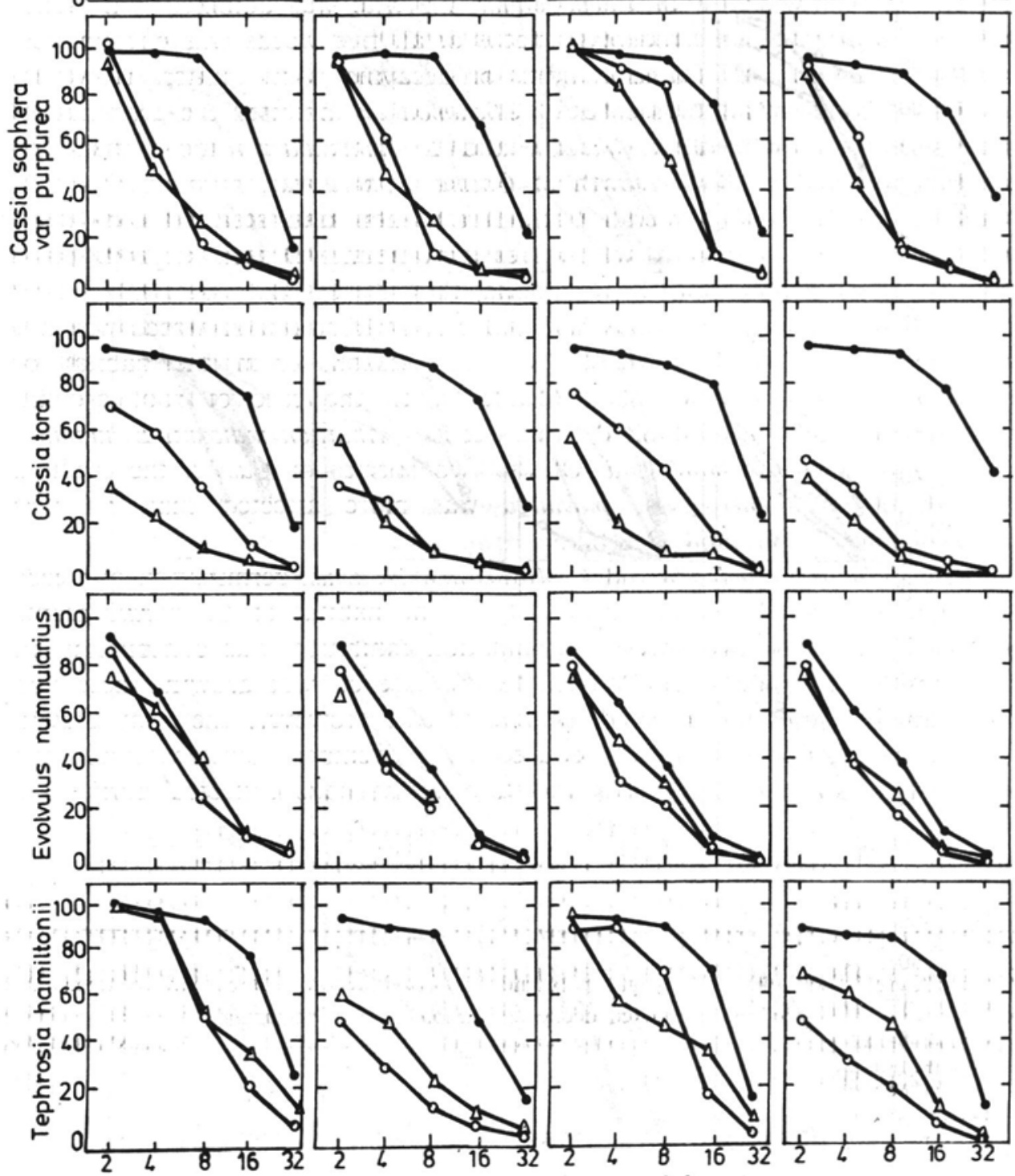

Amount of material [g]

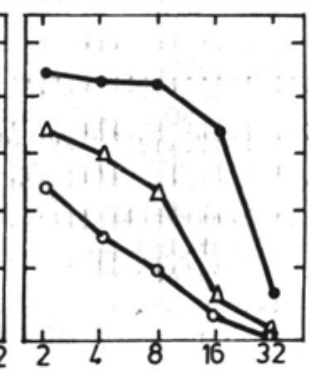


At lower concentrations, seedling growth usually was more reduced by the leaf-extract than by the leaf-leachate and more by leachates from $C$. ambrosioides than from those of $C$. murale.

Decaying plant-parts. Decaying leaves and inflorescences of Chenopodium, amounting to $2-8 \mathrm{~g}$ per $250 \mathrm{~g}$ soils, caused no germination reduction of Cassia sophera var. purpurea, C. tora and T. hamiltonii seeds (Fig. 2). However, germination inhibition of these three weeds took place when 16-32 g plant material of Chenopodium were incorporated into soils. While germination lowering of Abutilon indicum and Evolvulus nummularius was noteworthy when 4-32 g of Chenopodium material was admixed with soils, a decrease in root and hypocotyl lengths of all five weeds was encountered in the presence of the same quantity of decaying plant matter. However, decaying leaves and inflorescences of Chenopodium inhibited the germination and seedling growth of $A$. indicum and $E$. nummularius more than the germination and seedling growth of Cassia sophera var. purpurea, C. tora and $T$. hamiltonii. In general, both germination and seedling growth of weeds were more diminished with increasing amounts of decaying plant-parts of Chenopodium and more by $C$. murale than by $C$ : ambrosioides.

Field soils. Except Evolvulus nummularius, germination of weeds was not inhibited by soil collections of the three seasons from the habitat of Chenopodium ambrosioides plant (Table 1). In the case of root growth, soil samples uniformly inhibited three weeds - Abutilon indicum, E. nummularius and Tephrosia hamiltonii. Of the two species of Cassia, the seedling growth of $C$. sophera var. purpurea was more affected than $C$. tora particularly in April and October.

Except Abutilon indicum and Evolvulus nummularius, germination of weeds was not inhibited by soil-collections from the habitat of $C$. murale plants (Table 2). In these two species, germination inhibition was conspicuous in the months of January and March. In the case of root growth, these two soil samples adversely affected all five weeds. However, the root growth of the weed species was not reduced by November soils. Although the hypocotyl growth of the weeds was lowered by soils collected during the

Fig. 2. Germination (๑), root length (O) and hypocotyl length $(\Delta)$ of various weeds in loamy: soil mixed decaying Chenopodium plant-parts

Analysis of variance Germination

Root length Hypocotyl length Between the levels of: Amount of material

$\begin{array}{rr}\times & \times \\ \times & \times \\ \text { NS } & \text { NS } \\ \times & \times\end{array}$


three seasons, that of Cassia sophera var. purpurea was strongly inhibited by the March soils only.

Chemical nature of inhibitors. Extracts, obtained after soxhleting the leaf and inflorescence material of $C$. ambrosioides, were chromatographed over silica gel. Since active fractions from acetone extracts of both material were similar, data are not presented separately for each. Eluents were collected and the presence of active compounds was detected in each fraction. Germination as compared to control $(95-100 \%)$ was 0 in oily mass, (fractions 2-6 and 15-17). Values for root and hypocotyl lengths in the presence of solid residue (fractions 18-19) were $0.83 \mathrm{~cm}$ and $0.65 \mathrm{~cm}$ as against $2.00 \mathrm{~cm}$ and $1.04 \mathrm{~cm}$ in the control. Eluents from petroleum ether, $40-60^{\circ} \mathrm{C}$ (fractions 2-6), petroleum ether:benzene, 1:1 (fractions 15-17) and benzene (fractions 18-19) showed greenish violet colouration in Liebermann test. On evaporation of petroleum ether and petroleum ether:benzene eluents, a pungent oily resiude resulted and benzene eluent yielded a slightly aromatic solid residue, all appearing non-homogenous by TLC. These residues were taken separately in respective solvents in which they were eluted and filtered through a silica-gel column. These eluents were concentrated and their homogeneity tested in benzene:chloroform $(1: 1)$ and benzene solvent systems. In each case, a single spot was obtained. The $R$ values of petroleum ether, petroleum ether:benzene $(1: 1)$ and benzene fractions were 0.48 and $0.29,0.52$ and 0.46 and 0.75 and 0.60 respectively. No significant absorption peaks were obtained in the UV region. The IR spectrum of petroleum-ether eluent showed characteristic intense peaks at $3000,1600,1520$ and $825 \mathrm{~cm}^{-1}$ regions which indicated that the compound had $\mathrm{CH}$-streching, aromatic residue and aromatic substitution bonds. The IR spectral data of petroleum ether:benzene eluent produced peaks at 3000 $1650^{\mathrm{cm}}$ ' regions pointing to compounds with $\mathrm{CH}$-stretching and cis-disubstituted bond respectively. The benzene-eluted solid residue had peaks at 2950 , 1715 and $1650^{\mathrm{cm}^{-1}}$ regions showing that the compound possessed $\mathrm{CH}_{2}$-stretching frequency, $\mathrm{C}=0$ function and unsaturation respectively. The compounds existing in petroleum either, petroleum ether:benzene and benzene eluents were identified as p-cymene (bp. $176^{\circ} \mathrm{C}$ ), ascaridole (bp. $115^{\circ} \mathrm{C}$ ) and aritazone $\left(\mathrm{mp} .106^{\circ} \mathrm{C}\right)$ respectively and were confirmed with authentic samples. The toxicity $C$. ambrosioides leaf and inflorescence is very likely due to the prevalence of such compounds in each plant-part.

Extracts, after soxhleting the leaf and inflorescence material of $C$. murale, were chromatographed over silica-gel. The active petroleum ether $\left(40-60^{\circ} \mathrm{C}\right)$ eluent (fractions 1-2) showed green colouration with $\mathrm{FeCl}_{3}$ test and a solid residue was obtained. This eluent, on evaporation, yielded a greenish oily residue which had a slight smell and was found to be non-homogeneous by TLC. The IR spectrum indicated peaks at $3325,2980,2900$ and $1730^{\mathrm{cm}^{-1}}$ 
Table 1

Germination $(\mathrm{G})$, root length $(\mathrm{R})$ and hypocotyl length $(\mathrm{H})$ of various weeds in field soils previously in contact with $C$. ambrosioides plants

\begin{tabular}{|c|c|c|c|c|c|c|c|c|c|}
\hline \multirow{2}{*}{ Species } & \multicolumn{3}{|c|}{ Pre-monsoon (April) } & \multicolumn{3}{|c|}{ Monsoon (August) } & \multicolumn{3}{|c|}{ Post-monsoon (October) } \\
\hline & G & $\mathrm{R}$ & $\mathrm{H}$ & G & $\mathrm{R}$ & $\mathrm{H}$ & G & $\mathrm{R}$ & $\mathrm{H}$ \\
\hline Abutilon indicum & 98.0 & 55.61 & 53.48 & 99.0 & 84.88 & 142.79 & 97.0 & 45.36 & 48.13 \\
\hline $\begin{array}{l}\text { Cassia sophera var. } \\
\text { purpurea }\end{array}$ & 104.2 & 107.65 & 56.05 & 100.4 & 116.59 & 94.54 & 100.4 & 89.35 & 60.60 \\
\hline C. tora & 109.0 & 134.35 & 99.99 & 110.3 & 131.33 & 118.51 & 109.0 & 135.49 & 174.80 \\
\hline Evolvulus nummularius & 83.4 & 23.02 & 21.71 & 90.6 & 54.67 & 53.95 & 82.4 & 20.86 & 21.71 \\
\hline $\begin{array}{l}\text { Tephrosia hamiltonii } \\
\text { Analysis of variance: } \\
\text { between levels of }\end{array}$ & 121.1 & 77.64 & 79.29 & 124.4 & 72.35 & 81.65 & 118.5 & 57.05 & 90.53 \\
\hline $\begin{array}{l}\text { different species (4) } \\
\text { between levels of }\end{array}$ & $*$ & $*$ & $* * *$ & $*$ & $*$ & $* * *$ & $*$ & $*$ & $* * *$ \\
\hline different seasons (2) & $* * *$ & $* * *$ & NS & $* * *$ & $* * *$ & NS & $* * *$ & $* * *$ & NS \\
\hline
\end{tabular}

NS - not significantly different (P 0.05$)$ : * P $0.05: * * *$ P 0.001 . 
Table 2

Germination $(\mathrm{G})$, root length $(\mathrm{R})$ and hypocotyl length $(\mathrm{H})$ of various weeds in field soils previously in contact with $C$. murale

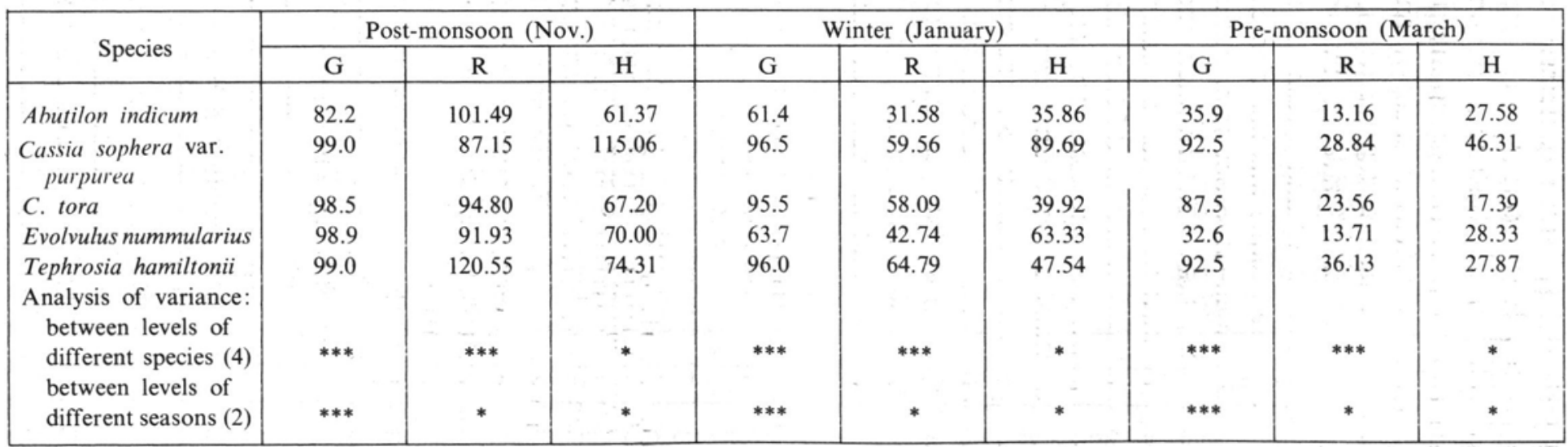


regions proving that this oily residue contained substances with carboxyl function, hydroxyl function and saturated $\mathrm{CH}_{2}$ chain. A small portion of the residue was taken in water, $\mathrm{NaHCO}_{3}$ solution was added slowly till effervescence appeared and a carboxylic group thus indicated. Another small portion of the residue was taken in alcohol and TLC was run with benzene:methanol:acetic acid:acetone $(80: 16: 10: 10)$ and ethanol. The solid residue was observed to be a mixture of two compounds. The active compounds showed $\mathrm{R}$ values of 10 and 0 respectively by using the two-solvent systems. Then the entire residue was taken in excess alcohol, warmed to dissolve it and kept overnight at room temperature. The solid appearing was filtered off, the mother liquor concentrated and left for crystallisation. The filtered solid was purified by repeated crystallisation from alcohol. The homogeneity of the solid was tested in different solvent systems; one spot (mp. $101.5^{\circ} \mathrm{C}$ ) was detected in each case. The IR spectrum of the active solid residue indicated peaks at 3500 and $1700^{\mathrm{cm}^{-1}}$ regions demonstrating hydroxyl and carboxyl function respectively. The solid residue did not show any significant absorption peaks in UV regions, was confirmed as an organic acid and found to be identical with an authentic sample of oxalic acid. The toxicity of both leaf and inflorescence of $C$. murale may be ascribed to the presence of this compound in each material.

\section{DISCUSSION}

The present study clearly demonstrated an inhibitory effect of the two plant-parts of Chenopodium on the seed germination as well as the root and hypocotyl growth of seedlings. Major toxicity was caused by $1: 2.5$ concentration of the inhibitor solution. Reducing the amount of leaf and inflorescence material in the preparation of an extract or leachate decreased the inhibition proportionately. However the degree of toxicity depends on the source plant, organ from which the inhibitor is prepared, type of inhibitor, concentration of inhibitor and weed species utilised in conducting the experiments. In general, the best effect of inhibition was indicated by the extract/leachate of leaves. While the washing of Chenopodium plant-organs helped in the loss of water-soluble inhibitors as per Cassia and Tephrosia bioassays, the loss was not vigorous enough to prevent phytotoxic action from taking place when extracts/leachates of washed plant matter were tried on Abutilon indicum and Evolvulus nummularius. In these two species, there was differential action of the leachate and extract. With A. indicum, leachates of leaves or inflorescences were more effective than extracts of the corresponding organs. With E. nummularius, the leaf-extract was more effective than the leaf-leachate and the inflorescence-leachate more than 
the inflorescence-extract. It is very likely that inhibitors are readily available in the extract of leachate. Although it is not clear whether extracts/leachates of Chenopodium ambrosioides and $C$. murale were equally effective on all the five weeds investigated, non-leguminous weeds $-A$. indicum and $E$. nummularius - were more sensitive to inhibitor solutions made from Chenopodium than leguminous weeds - Cassia sophera var. purpurea, C. tora and Tephrosia hamiltonii. Perhaps the genetical constitution of legumes renders them less susceptible to phytotoxicity by extracts and leachates from Chenopodium.

Like the extract and leachate of washed plant-parts, decaying leaves and inflorescences of Chenopodium (admixed with soils) were highly effective against $A$. indicum and $E$. nummularius. While the germination inhibition of these two weeds would occur with the use of a minimum amount $(4 \mathrm{~g})$ of plant material, the seed germination of Cassia sophera var. purpurea, $C$. tora and $C$. hamiltonii could ensue when four times as much material was used. Furthermore, the root and hypocotyl growth of all weeds were uniformly inhibited by decaying plant matter; such an action was enhanced by the increasing incorporation of the concerned decaying plant-part with soils. Though it is difficult to pinpoint whether decaying leaves were more potent than decaying inflorescences, greater reductions were brought about by Chenopodium murale than by $C$. ambrosioides. Evidently, more inhibitors generated from C. murale than from C. ambrosioides. This, however, stands as a contrast to the experiment with extracts/leachates where the difference between the phytotoxic action of the two species of Chenopodium could not be established. The respective plant-parts were washed in the case of the extract/leachate. In decaying plant matter, each plant-part was not washed but allowed to undergo weathering. Nevertheless, non-leguminous weeds were more adversely affected by decaying plant parts than leguminous weeds. In decaying leaves or inflorescences, inhibitors are gradually detoxified and their synthesis, if any, is not commensurate with the decaying process.

The significance of the inhibitory effect of extracts/leachates or decaying plant-parts of Chenopodium on other species in natural conditions is not known as yet. Since the life-cycle of $C$. ambrosioides differed from that of $C$. murale, it was inconvenient to collect all soil samples from the habitat of these species in the same season and assess the activity of these soils simultaneously. Despite this fact, more inhibitors were available from the habitat of $C$. ambrosioides plants in the post-monsoon period (October) than in other seasons. In the case of $C$. murale plants, more inhibitors were released in the pre-monsoon period (March) than in other seasons. As far as the weed species are concerned, soil-collection experiments showed germination inhibition of Evolvulus nummularius seeds by soils around C. ambro- 
sioides plants as well as germination inhibition of $E$. nummularius and Abutilon indicum seeds by soils around $C$. murale plants. In the post-monsoon period, soils collected from $C$. murale fields not only inhibited the seed germination of $A$. indicum and $E$. nummularius but also the root growth of these two non-legumes along with the legumes-Cassia sophera var. purpurea, C. tora, and Tephrosia hamiltonii. As to the hypocotyl growth of the two species of Cassia, the effect of soil samples was stronger on $C$. sophera var. purpurea than on $C$. tora; here soils were more phytotoxic in the pre-monsoon (April) and post-monsoon (October) from $C$. ambrosioides fields and pre-monsoon (March) from $C$. murale fields. In field soils, inhibitors arise from the litter discarded by plants as well as from plants themselves which are no longer in the stage of active growth. This may be accentuated by prevailing environmental conditions, such as (1) a water deficit/excess in the species usually developed as a consequence of drought/saturated conditions; (1) low/high temperatures, (2) reduced/enhanced light intensity and (3) change in the length of the photoperiod. Thus, the phytotoxicity of soils collected in and around the habitat of Chenopodium plants depends not only on the season when collections are made but also on the weed species on which they are applied and the responses elicited.

The allelopathic pattern varied in each species of Chenopodium in view of the inhibitor content differing in the extract/leachate, decaying plant-part and field soil. In all cases, the seed germination and seedling growth of Abutilon indicum and Evolvulus nummularius were seriously affected. It is for this reason that these two non-leguminous species are rarely found in the habitat of Chenopodium plants, particularly of $C$. ambrosioides. In the proximity of $C$. ambrosioides, species of Cassia and Tephrosia generally prevail and may reveal stunted growth during certain seasons when inhibitors accúmulate from the source plant.

The chemical nature of inhibitors produced by higher plants is well documented (Evenari 1961, Datta and Sinha-Roy 1974, Rice 1984). From the present work, one can have a bird's eye-view of inhibitory substances from the two species of Chenopodium. Though the quality of inhibitors varied from one species to another, extracts/leachates of leaves usually exhibited a greater allelopathic effect than extracts/leachates of inflorescences. This being so, the leaf materials from Chenopodium ambrosioides and $C$. murale were subjected to chemical analysis. Extracts of C. ambrosioides contained a group of terpenes - p-cymene, ascaridole and aritazone - compounds which may be considered as allelopathies. On the other hand, the allelopathic potential in $C$. murale may be attributed to the presence of a toxic complex having an organic acid (oxalic acid) as one of the constituents. 


\section{REFERENCES}

Bhati P. R., Ashraf N., Sen D. N., 1979. Ecology of Indian arid zone weeds. VII. Chenopodium spp. Geobios 6: 20-23.

Chopra R. N., Badhwar R. L., Ghosh S., 1965. Poisonous plants of India. Vol. 2, Indian Council of Agricultural Research, New Delhi, pp. 715-719.

Datta S. C., Sinha-Roy S. P., 1974. Allelopathy and inhibitors. Sci. Cult. 40:' 47-59.

Datta S. C., Paria N. D., Ghosh K. N., 1978. On the occurrence and distribution of a crop-field weed-Chenopodium murale Linn. in West Bengal. Sci. Cult. 44: 229-230.

Evenari M., 1961. Chemical influences of other plants (Allelopathy). In: Handbuch der Pflanzenphysiologie. W. Ruhland (ed). Vol. 16, Springer-Verlag, Berlin, pp. 690-736. Harper J. L., 1977. Population biology of plants. Academic Press, New York. pp. 369-381. Maheshwari J. K., 1963. The flora of Delhi. Council of Scientific and Industrial Research, New Delhi. pp. 301-302.

Maheshwari P., Singh U., 1965. Dictionary of economic plants in India. Indian Council of Agricultural Research, New Delhi. p. 39.

Putnam A. R., Duke W. B., 1978. Allelopathy in agro-ecosystems. Ann. Rev. Phytopathol. 16: 431-451.

Rice E. L., 1984. Allelopathy. 2nd ed. Academic Press, New York. pp. 266-291.

Salisbury F. B., 1957. Plant growth substances. Sci. Amer. 193: 125-134.

\section{Allelopatia u dwóch gatunków Chenopodium - inhibicja kielkowania $i$ wzrostu siewek chwastów}

\section{Streszczenie}

Badano wpływ przepłuczyn liści i kwatostanów Chenopodium ambrosioides i C. murale, ich zamierających liści i kwiatostanów oraz ziemi zebranej pod tymi roślinami na zmniejszanie kiełkowania i wzrostu siewek pięciu gatunków chwastów: Abutilon indicum, Cassia sophera var. purpurea, C. tora, Evolvulus nummularius, Tephrosia hamiltonii. Obserwowany rodzaj allelopatii zależał od gatunku Chenopodium i był różny u różnych chwastów. Fitotoksyny lub inhibitory z Chenopodium dużo bardziej ograniczały zarówno kiełkowanie, jak i wzrost korzenia i hypokotyla $A$. indicum i $E$. nummularius niż pozostałych chwastów. Ponieważ liście i kwiatostany Chenopodium są źródłem inhibitorów, dlatego analizowano je chemicznie i stwierdzono występowanie trzech terpenów (p-cymen, askaridol i aritazon) u C. ambrosioides i kwasu organicznego (kwas szczawiowy) u C. murale, które to związki wykazały zdolności allelopatyczne. 